\title{
EVALUATION OF COMMERCIAL PROPERTY MARKET MATURITY: A CASE OF LITHUANIA
}

\author{
Viktorija COHEN ${ }^{a^{*}}$, Birutė GALINIENÉ ${ }^{a}$ \\ ${ }^{a}$ Department of Economic Policy, Vilnius University, Sauletekio al. 9, II bld., room 807, \\ LT-10222 Vilnius, Lithuania
}

Received 7 March 2013; accepted 2 July 2013

\begin{abstract}
Property market maturity level is one of the influential factors affecting competitiveness of a country in a global arena. Local economies of Central and Eastern Europe may have reacted differently to the economic globalisation process, but property markets in these countries became very much dependent on global trends in terms of market development, evolution and adaption of practices. This article analyzes scientific observations and aspects of property market evolution, suggests a model of property market evolution and adapts the property market maturity concept, applying it in the case of the Lithuanian commercial property market. This article also presents the results of a survey among the commercial property market actors, which mainly suggests the level of property market maturity. The results indicate that although the overall market degree of maturity still needs to be improved, the elements of professional services, the actors' activity, the investment market environment and the flow of information ranked better maturity, compared to the other elements used in the study.
\end{abstract}

KEYWORDS: Commercial property market; Market maturity; Market maturity phases; Globalization; Evolution; Transition; Competitiveness; Actors; Economic growth; Financial sector

REFERENCE to this paper should be made as follows: Cohen, V.; Galinienè, B. 2014. Evaluation of commercial property market maturity: a case of Lithuania, International Journal of Strategic Property Management 18(2): 151-162.

\section{INTRODUCTION}

The evolution of the commercial property market in Central and Eastern Europe shows great transformation during the last twenty years. The degree to which these markets evolved depends on institutional, legal, political and economical pathways that were adopted by economies and their openness to globalization. Globalization, on the other hand, focuses on how local property markets respond to the dynamics of transformations and tendencies adopted and used by the rest of the world (Tasan-Kok 2007). Offering increased financial mobility of the international investment globalization process positions international property investors seeking capital profitability in the countries with promising opportunities. However, the degree of property market maturity can encourage or dis- courage investors to take a certain risk by investing in a given country. Moreover, it can illustrate a relative measure to which certain changes of socio-economical and institutional integration are put into practice. For that reason, this paper attempts to evaluate the level of property market maturity in case of Lithuania adopting Keogh and D’Arcy (1994) property market maturity paradigm.

The paper is structured into six sections following this introduction. Section two describes the concept of property market maturity; influence of globalization and the evolution of the property market in Lithuania is presented in section three; methodology used to evaluate the property market maturity is outlined in section four, following discussion of the results in section five. Finally, concluding remarks are provided in section six.

\footnotetext{
* Corresponding author. E-mail: viktorija.cohen@ef.vu.lt
} 


\section{CONCEPT OF PROPERTY MARKET MATURITY}

Property market maturity term is not widely analyzed in academic literature. This term became more acknowledged when new markets nurtured the creation of property markets. The concept of property market maturity was first presented by Keogh and D'Arcy (1994) as a measure of cities' competitiveness and attractiveness and has been regarded as the most comprehensive approach in this respect (Lim 2000; Lee 1999, 2001; Chin, Dent 2005). Although the concept of property market maturity has been applied more to the markets of developed economies, it can be used as an informative tool measuring evolution and transition of property markets in developing markets. Within the market maturity paradigm, Keogh and D'Arcy (1994) identify six principal aspects of a mature property market, which are outlined in Table 1.

Keogh and D'Arcy (1994) argue that maturity of the property market is not a process with an absolute finished accomplishment, it is rather a process that depends on market development routes and time periods to reach it, taking into account specific markets' processes and institutional forms. In other words, there is no specific path for all evolutionary property markets to follow. Among criteria that characterize a mature property market, scientists include data transparency, market information, developed property services, property transactions and the presence of foreign property investors in the market (D'Arcy, Keogh 1998; Keogh, D'Arcy 1999). Yet, Seek (1996) considers maturity being the fundamental goal of the property market. It is likely that market evolution, development processes, and specific market transforma- tion mechanisms will include several phases to reach market maturity. According to Seek (1996) these phases might be classified as an initial phase, an overbuilding phase, a maturing phase, a mature phase and a post mature phase. Therefore, it might be a good argument for adjusting the paradigm of market maturity, to developing or emerging economies and countries in transition, as one of the key objectives of these economies in reaching its attractiveness and competitiveness in the global arena.

Several studies applied the market maturity paradigm for evaluating the level of property market maturity. McGreal et al. (2002) examined the degree to which central European cities such as Budapest, Prague, and Warsaw have adapted to global influences in relation to the development of commercial property markets. For this purpose, the research methodology was formed using a focus group technique, conducted in Budapest, Prague, and Warsaw supported by secondary data of market reports and a structured interview. The analysis addressed four main subjects in terms of the commercial property sector: rationale for investment, factors influencing property investment (emphasizing taxation, information, financing, ownership), policy mechanisms and institutional perspectives and future development. The overall results in terms of property market maturity indicated an immature level and identified an information deficit. Efficiency in professional services represented by international real estate companies proposes several key factors of maturity: structural changes on an institutional level and clear ownership structure.

Chin and Dent (2005) using the framework of Keogh and D'Arcy (1994) adopted it in an at-

Table 1. Characteristics of a mature property market

\begin{tabular}{|c|c|}
\hline Principal aspects & Characteristics \\
\hline $\begin{array}{l}\text { A market's ability to accommodate a full } \\
\text { range of use and investment objectives }\end{array}$ & $\begin{array}{l}\text { Existence of a well-developed investment market environment: } \\
\text { - full range of investment objectives } \\
\text { - diverse demand of occupiers for space } \\
\text { - developed investment culture } \\
\text { - no burdens of ownership }\end{array}$ \\
\hline $\begin{array}{l}\text { Flexibility in a market's adjustment in short } \\
\text { and long term }\end{array}$ & $\begin{array}{l}\text { Effective property trade and market actors' ability to react to new } \\
\text { information and opportunities }\end{array}$ \\
\hline $\begin{array}{l}\text { Existence of sophisticated property profession } \\
\text { with associated institutions and networks }\end{array}$ & A market's regulation and professional market players' practice \\
\hline Extensive information flow & Transparency level of the market \\
\hline $\begin{array}{l}\text { Market openness in spatial, functional } \\
\text { and sectoral terms }\end{array}$ & Allowance of market players to operate with no boundaries \\
\hline $\begin{array}{l}\text { Standardization of property rights and market } \\
\text { practices }\end{array}$ & Role for local property market culture \\
\hline
\end{tabular}

Source: Keogh and D'Arcy (1994). 
tempt to measure the similarities and differences between five Asian property markets' maturity performance. Face-to-face interviews with a total of 50 respondents were conducted, where each element was assessed on a scale from 1 to 5 , where 1 meant "very well developed" and 5 meant "very limited development". In addition, elements used by Lee (2001) were included: the quality of property product, market information standardisation and availability, and the presence of property intermediaries. The results suggested that Hong Kong and Singapore were mature markets; Kuala Lumpur, Bangkok, and Taipei were emergent markets. Furthermore, the study confirmed the requirements of a mature market offered by Keogh and D'Arcy (1994) should be able to accommodate the complex requirement for use and investment activities, offer extensive information flows and research activities, offer an open environment in spatial, functional, and sectoral terms, and present an extensive property profession with its institutions and networks and provide a high level of capital liquidity.

Most recent study of Cohen and Galiniene (2012) addressed the maturity of the Lithuanian property market, providing some insights into the evolution and developments of the market and adopting market maturity paradigm as a basis for the research. Based on four principal aspects highlighted by Keogh and D'Arcy (1999), the research examines property service provision, market information, the property investment market, and the importance of foreign market players and funds in the market, taking into account local culture and historical market development factors. The study concludes that although the market maturity is in its maturing phase, processes of a legal system and institutional reforms and foreign investors' activities in the market had a major influence on the market's development towards property market maturity.

\section{MODELING COMMERCIAL PROPERTY MARKET EVOLUTION IN LITHUANIA}

The evolution of commercial property market in Central and Eastern European countries is a significant part of the transformation process from centralized control regime to market-based economy. Often referred to as economies in transition, these countries created institutional framework that now provides a foundation for democratic regimes (see e.g. Kauko 2012). Transition of all these economies has been uneven and its outcome differs significantly; some had great improvement and others made slight progress moving towards an efficiently operating property market (Adair et al. 2006). A combination of institutional and economic reforms, privatization, and liberalization of various barriers were major factors influencing attractiveness of new market-based economies to foreign investors. According to some scholars, all these factors coincided with the growth of global forces in the 1990's and therefore globalization has had a major influence and affected cities in ways of economic and physical transformation, and had important consequences to the growth and development of the property market (Rykiel 1998; Clark, Lund 2000; McGreal et al. 2002; Jones Lang Lasalle 2007; Cohen 2012; Raslanas, Lukošienè 2013). Ritzer (2003) argues that globalization refers to standardization of images, products, buildings and market actors' behavior around the world. In fact, one can quite easily recognize that commercial property can be characterized as a globally standardized product with similar physical elements of location, size, shape, architectural design, use of space etc. Adaption of trends that are developed worldwide and existence of such buildings in a city usually is taken as a sign to be internationally recognized. On the other hand, Tasan-Kok (2007) suggests that globalization does not necessarily create a prototype for cities' development; it rather produces so-called "global urban forms" patterns. Yet, shape and content of the commercial projects is influenced by local contingency and therefore must be adjusted based on country-specific strategy (Tasan-Kok 2007), requiring different types of strategic decisions and management passing through building life stages (Tamošaitienè, Gaudutis 2013).

In spite of this, institutional development cannot be standardized as easily as physical appearance of a building. Cohen and Galinienè (2012) argue that the main driving forces in property market formation were institutional forces that occurred during the market transformation process from command market regime to market economy and can be distinguished as follows:

- Legal framework and tax restructuring;

- Institutional reform;

- International investors and companies' appearance in the market;

- Economic growth factors;

- Structural changes in financial service.

Although McGreal et al. (2002) argue that changes in legal and tax systems were subjected to frequent adjustments, regulations were often 
conflicting and unclear, land legislation was developed poorly and foreign investors had notably few investment guarantees. Adair et al. (2006) state that principal economies have progressed rapidly in terms of property market development by reducing obstacles to foreign investors, in connection to privatization and property law. In the Baltic States formation of institutional market model set the underpinning of the property market, as legal framework and privatization played the main factor for property market functioning. Transformation and evolution of the economy together with the demand for new large-scale commercial property (such as shopping centers, malls, hypermarkets, office buildings etc.) brought in new investors, affecting the behavior of local actors. Commercial property actors and especially their behavior and interrelation play an important role in the market formation based on their experience, needs, demand, and supply.

A major impact of the evolutionary process of the property market development in Lithuania demonstrates physical transformation of the cities and demand for office and retail space between 2000 and 2008. This supported with contention of the last decade's market tendencies proved a sharp change in the beginning of this century. Fig. 1 demonstrates evolutionary process of changes in the property market between the initial stage of the property market development in 2000 and present. Commercial property space (in particular offices and shopping centers) in the country emerged greatly: from no space in 2000 , to 850 thousand sq. meters in shopping centers and almost 500 thousand sq. meters of A and B class office space for the major cities of Vilnius, Kaunas, and Klaipèda in 2012 (Ober Haus 2012).

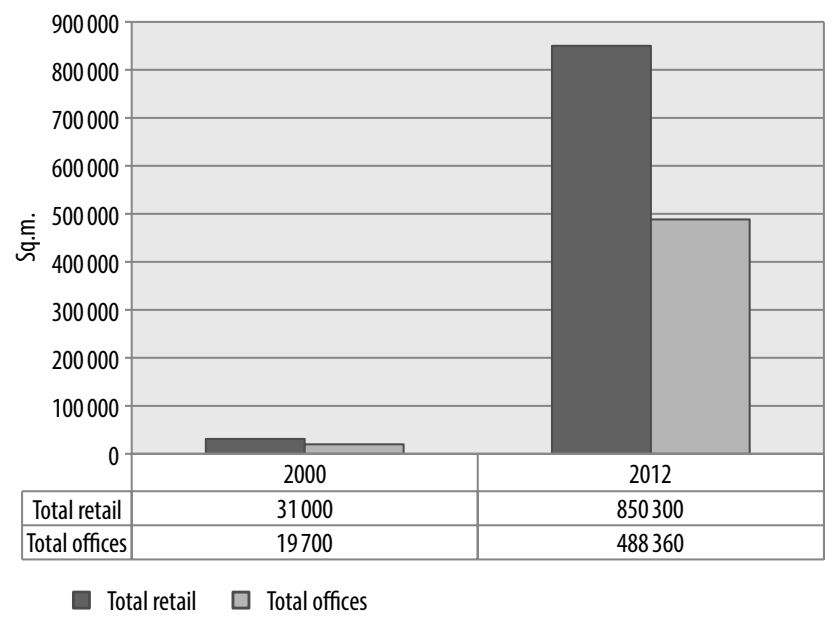

Fig. 1. Commercial property space difference in Lithuania in 2000 and 2012
Particularly, changes in the property market development greatly influenced the entire economy. According to D'Arcy and Keogh (1999) property development stimulates demand for space and promotes country's economic activity and the success of that strategy depends on the supplydemand requirement based on the economic potential, generating the required financing, sharing risk efficiently, applying right market expertise. Kolbre and Kallakmaa-Kapsta (2006) point out that strong and rapid growth rates in the Baltic countries, were the incentive of the "catching-up process", which is accurate in terms of supply and demand imbalance and short-term market economic changes. However, this process has had negative effect in the long-term. Property market in Lithuania witnessed exceptionally high investment incentives and price uncertainty. Ramanauskas (2005) warned that active banks' credit policy was one of the main factors in increasing domestic demand and promoting economic growth, which in turn accelerates the investment and borrowing, the onset of the financial accelerator mechanism. Unbalanced credit portfolio growth and poor application of economic policy measures produced short-term loan-driven economic growth (Jakeliūnas 2010).

There is a close interconnection between a country's economy and the development of the property market, and real estate in general, providing economic prosperity or economic slowdown depending on activities in the property market. According to Barras (1994) and proven historical trends in Lithuania (Fig. 2) the financial market also plays a vital part by directly influencing both the economy and property market and therefore there is a close interrelation between all three sectors.

Fig. 2 can also be used in phasing the evolution of the property market in Lithuania. Researchers refer to different phases in evolution and development of property markets in Central and Eastern Europe. Adair et al. (1999) propose three stages of property market formation: initial stage, entry of foreign firms, and growth of supply through the development market. Watkins and Merrill (2003) identify four stages in property market evolution and development: inactivity, cautious beginnings, hyper-growth, and seeking equilibrium. Analyzing residential real estate in Lithuania Ivanauskas et al. (2008) analyzed a three-stage market development framework characterized by periods of 1992-2002, 2002-2005, and 2005-2006. Bearing this in mind, the evolution of the property market in Lithuania can be characterized by seven stages of its development (Table 2). 


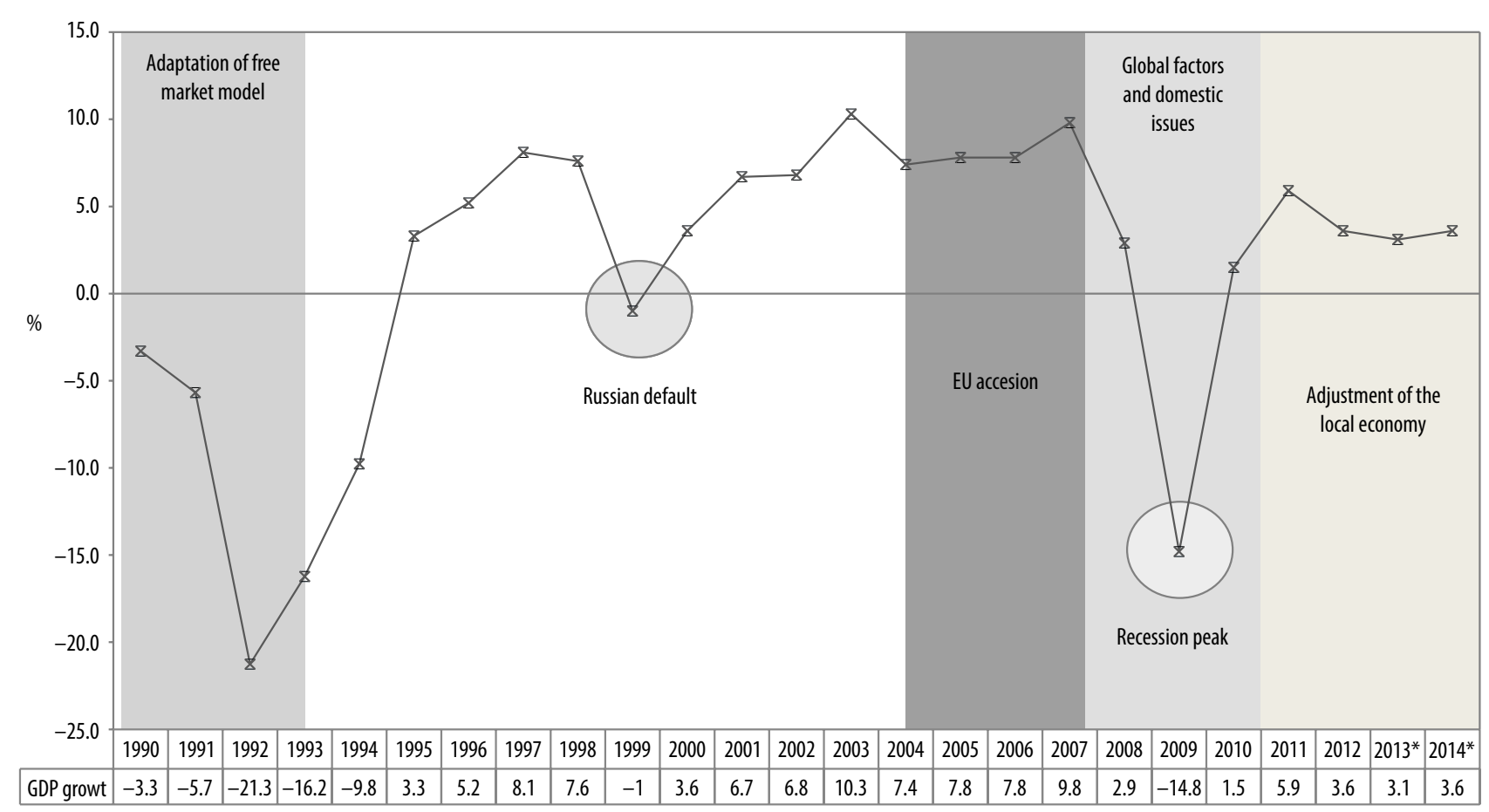

Fig. 2. GDP growth

Table 2. Property market development and evolution in Lithuania

\begin{tabular}{lll}
\hline Stages & Period & Market trends \\
\hline I & $1991-1995$ & $\begin{array}{l}\text { Market transition, adaptation, } \\
\text { legal and political system restruc- } \\
\text { turing, privatization and institu- } \\
\text { tional reform. }\end{array}$ \\
II & 1995-2002 & $\begin{array}{l}\text { Beginning of commercial property } \\
\text { market development: supermar- } \\
\end{array}$ \\
& & kets, shopping centers and office \\
& buildings.
\end{tabular}

2002-2005 Increase in residential real estate market construction. Macroeconomic stabilization.

Growth in bank lendings.

IV 2005-2006 Residential real estate market booming. Banks' loan portfolio growth. Commercial real estate market activity. Euro as a currency adoption plan.

\section{Characteristics}

The economy is adapting a framework of free market foundations and regulations in forms of reforms and restructuring political and legal environment, monetary system and different macroeconomical factors.

Growing demand for commercial property market. The supply of modern commercial real estate began showing up in 1999-2000. There are signs of market growth, growing foreign investors' interest in the market's attractive high yields; change in service towards customers and working environment. Yet, reforms and legal environment still being improved.

Often referred to as "overheated" (Ivanauskas et al. 2008) stage, supported by rapid and unjustified growth in costs and prices (30-50\% early price growth). One of the biggest factors played EU accession, improved and growing lending, macroeconomic growth and speculative intentions.

In light of Euro introduction plans, lack of construction labor and easy access to loans residential real estate experienced rapid price growth (apartment prices on average increased $50-120 \%$ in one year), creating a bubble concern in residential real estate.

V 2006-2008 Commercial property market booming.

Rapid growth in number of issued building permits and commercial property development. Increase in rents and yields.

VI 2008-2010 The global economic downturn, recession and contraction.

VII 2010-now Searching for equilibrium, market adaptation.

Shrinkage of macroeconomic indicators, tightened financing, drop of rental rates, decrease of property values, a wave of bankruptcies, decrease in demand and growth in vacancies.

While demand is limited, market adjusts to the post crisis needs; rental market is sensitive and prices hit the bottom. Nevertheless, the development of the commercial projects that was halted during the crises is coming back to the ongoing construction. Both minor and major commercial property transactions are closed. 
Table 1 suggests that each stage represents the property market development process, whereas market formation principles lie in institutional model in forms of political and legal reforms, monetary policy, and macroeconomic processes representing the foundation of property market formation. Improvements of both quantitative-driven factors, such as economical and financial, and qualitativedriven factors in form of the structural changes, specific cultural influence, technology etc. result in market competitiveness and encourage investment and general market participants' responses in the market, influencing market maturity (Fig. 3).

The model mainly reflects that all the processes and mechanisms implemented both during the property market formation period and its current functioning are oriented towards improved market competitiveness, which in turn generates property market responses and affects its maturity. Notably, the effect of globalization increased the importance of competition between different countries and therefore qualitative factors of an individual country play an important role in global economy. Globalization forces, economic integration processes bring structural changes to the economies. As economies emerge and develop, capital flows freely across different countries and national boundaries, actors (property investors, developers, advisors) of the property market increased the demand and brought changes within the property market to meet the requirements of the clients. At the same time, these developments have made individual markets more vulnerable to changes in global economy, international capital flows and financial markets (D'Arcy, Keogh 1999), a good example is recent Global financial crises in 2007-2008 that still has major impact on most countries. Obviously, technological development in supporting these processes played ultimate part. Economic integration requires structural changes within the local political and institutional environment, additional policy measures and instruments, and sustainable development that overall improve market's competitive advantage.

\section{RESEARCH METHODOLOGY}

The aim of this research methodology is to evaluate the property market maturity in Lithuania. For this purpose a questionnaire was designed and conducted in September - October 2012 where the primary data was collected from using structured techniques. The survey questions were aimed to obtain objective views from the commercial property market actors. According to Wu et al. (2009) opinions of major commercial market actors form

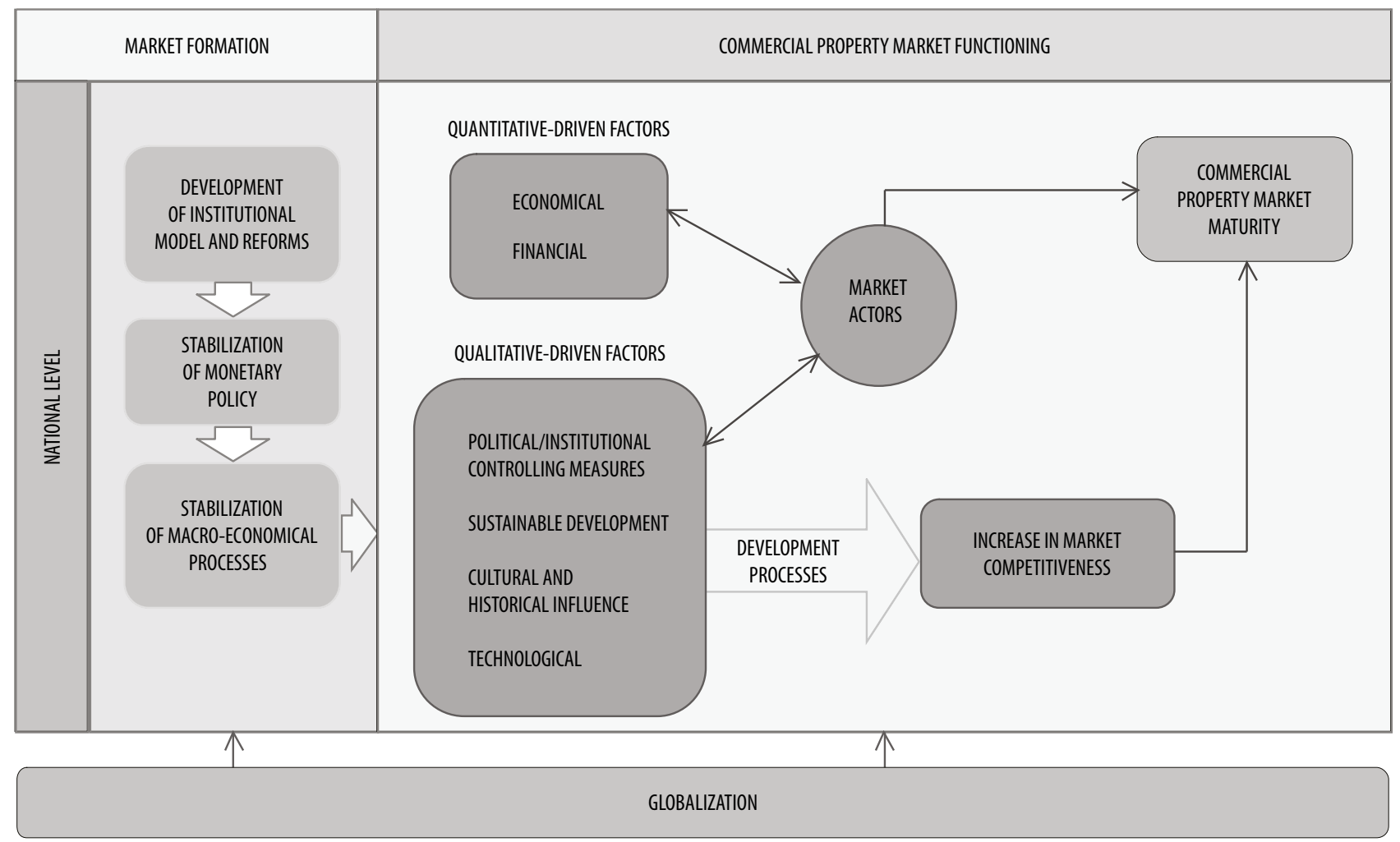

Fig. 3. Model of property market evolution 
constructive insights on obtaining evaluation of the market. The target respondents in the research are main market actors in commercial real estate that are outlined in Table 3. The study of Keogh and D'Arcy (1994), which offered six principal aspects for assessing a mature market, was used as a ground for developing a questionnaire survey. In addition, the survey included elements of market transparency, professional services, market research level, market actors' competences, and market flexibility elements. Statements from the questionnaire and classification of the elements are outlined in Table 4. The respondents were offered to use Likert scales technique ranging from 1 to 5, where 1 meant absolute disagreement with a statement about a particular element (or very immature level of the element) and 5 meant absolute agreement (or very mature level of the element) with 13 statements in terms of commercial property market elements.

For the purpose of this research the participants were divided into three groups: commercial property producers, institutions, and experts and formed $0.9 \%, 100 \%$ and $4.5 \%$ of the total segment's population respectively.

Table 3. Survey participants

\begin{tabular}{llll}
\hline & Survey participants & Population $\%$ \\
\hline $\begin{array}{l}\text { Commercial } \\
\text { property }\end{array}$ & $\begin{array}{l}\text { Owners } \\
\text { market } \\
\text { producers* }\end{array}$ & $\begin{array}{l}\text { Occupiers } \\
\text { Developers }\end{array}$ & $\begin{array}{l}\text { Investors } \\
\text { Institutions** }\end{array}$ \\
& $\begin{array}{l}\text { Banks } \\
\text { Governmental } \\
\text { institutions }\end{array}$ & 15 & $0.9 \%$ \\
Experts*** & $\begin{array}{l}\text { Valuators } \\
\text { Consultants } \\
\text { Researchers } \\
\text { Associations and } \\
\text { organizations alike } \\
\text { connected to } \\
\text { commercial property }\end{array}$ & 665 & \\
& & $4.5 \%$ \\
\hline Total & 4111 & - \\
\hline
\end{tabular}

Notes: *Based on Lithuanian Department of Statistics in the beginning 2012 there were registered 3431 operating entities involved in property market;

**This segment consists of 11 banks operating in Lithuania (as of October 2012) and four state agencies (State Territorial Planning and Construction Inspectorate under the Ministry of Environment, Ministry of Economy, Ministry of Environment, Ministry of Agriculture). This entire segment equals to 15 entities;

$* * *$ This segment consists of commercial property market researchers ( 25 subjects), property market evaluators (a total of 290 reviews and 305 of their assistants), property market consultants (online business directory, Lithuania has 45 real estate advisory services company) and other experts. The entire segment makes approx. 665 individuals. It is assumed that the number of property market experts equals the number of entities.
A total of 75 responses were received out of 101 deliverable surveys either e-mailed $(70 \%)$ or handed out personally (30\%) to a pre-selected, but not random respondents. Twenty-six (25.7\%) of the total did not respond after a few attempts to contact them. Seventy five $(74.3 \%)$ participants responded by e-mail and personal meetings. $31.5 \%$ of respondents to this survey were at a higher level in the organization and typically had more than 10 years experience in the property market.

Cronbach's alpha reliability coefficient $\alpha$ is applied being imperative to use when applying Likert-type scales to report Cronbach's alpha for internal consistency reliability (Gliem, Gliem 2003). It is also considered to be the most popular method in computing reliability or accuracy of measurements (Cronbach, Shavelson 2004; Zinbarg et al. 2005; Egerová et al. 2013). Cronbach's alpha coefficient normally ranges between 0 and 1 , where 1 means greater the internal consistency of the items in the scale. The following rule of thumb is provided in the literature (George, Mallery 2003):

\begin{tabular}{ll}
\hline Cronbach's alpha & Internal consistency \\
\hline$\alpha \geq 0.9$ & Excellent \\
$0.8 \leq \alpha<0.9$ & Good \\
$0.7 \leq \alpha<0.8$ & Acceptable \\
$0.6 \leq \alpha<0.7$ & Questionable \\
$0.5 \leq \alpha<0.6$ & Poor \\
$\alpha<0.5$ & Unacceptable \\
\hline
\end{tabular}

A nonparametric one-way analysis of variance - a Kruskal-Wallis test - is conducted to explore whether the opinions and assessment of the statements for commercial market maturity level differ between the three groups of respondents. In other words, it is used to determine whether differences between groups of data have significant or non-significant differences (Dipo, Soekarno 2012). This test is appropriate if the following conditions are met: there are three or more conditions to compare, each condition should be performed by a different group of participants, and data should not meet the requirements for a parametric test. Since these requirements are met, $p$-value (Asymp. Syg.) is calculated based on the following description:

\begin{tabular}{ll}
\hline If $\alpha$ is significance level, $p$ is $p$-value \\
\hline $\begin{array}{ll}\text { If } p<\alpha-\mathrm{H}_{0} \text { rejected, } & \text { If } p \geq \alpha-\mathrm{H}_{\mathrm{A}} \text { fail to reject. } \\
\text { where: } \alpha=0.05 & \text { where: } \alpha=0.05\end{array}$ \\
$\begin{array}{ll}\text { The differences between } \\
\text { groups of data are }\end{array}$ & $\begin{array}{l}\text { The differences between } \\
\text { groups of data are not }\end{array}$ \\
statistically equal & statistically equal
\end{tabular}




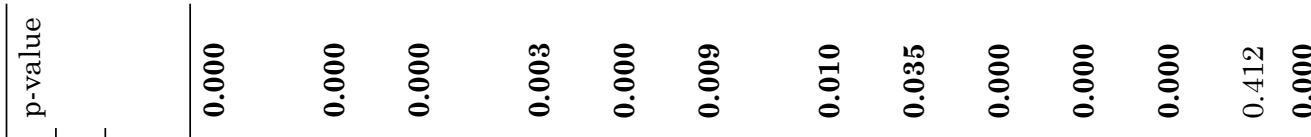

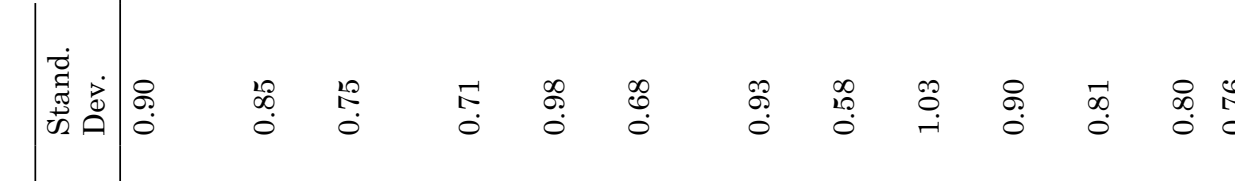

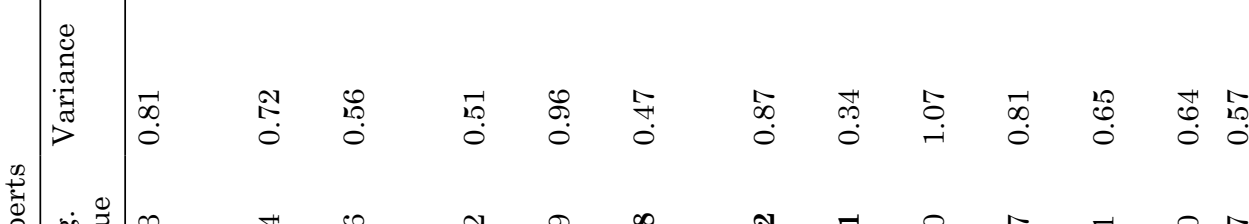

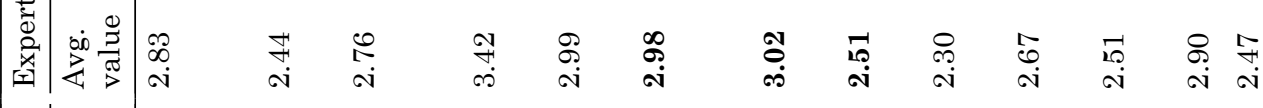

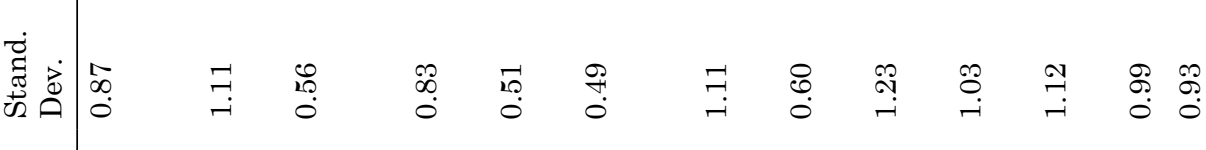

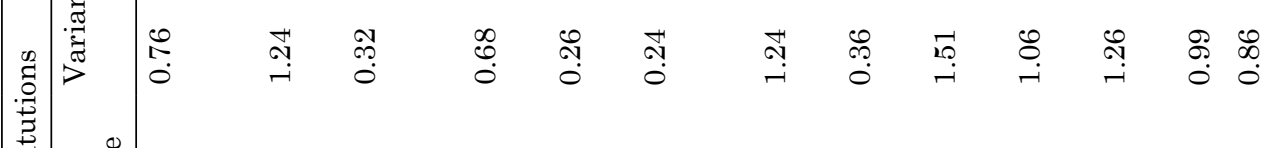

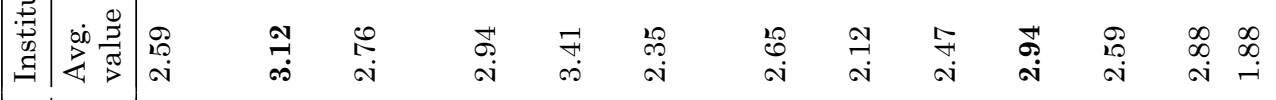

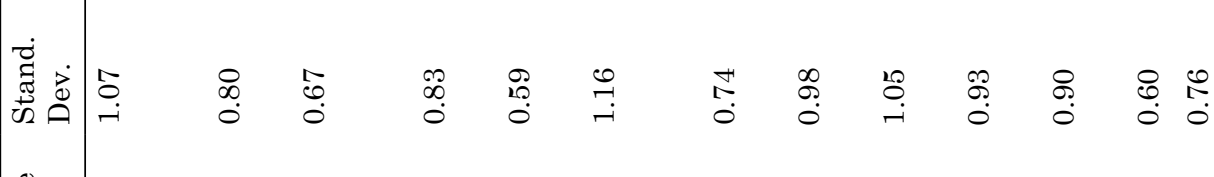

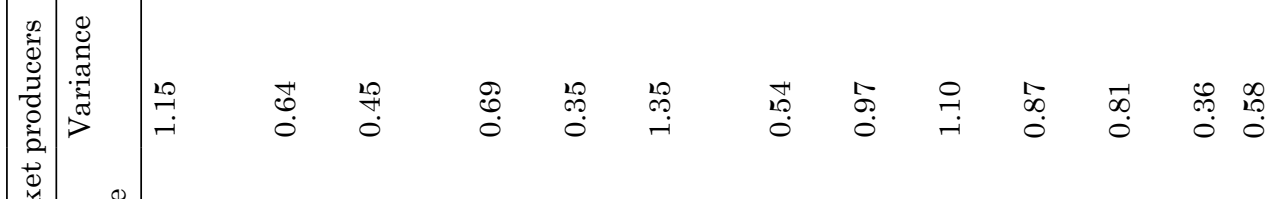

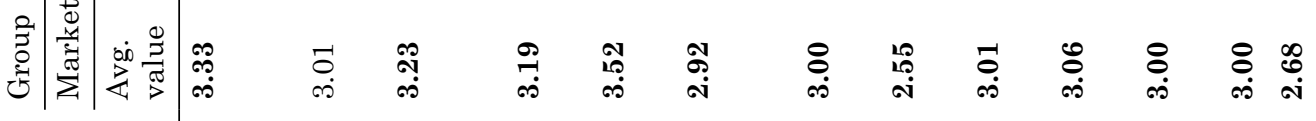

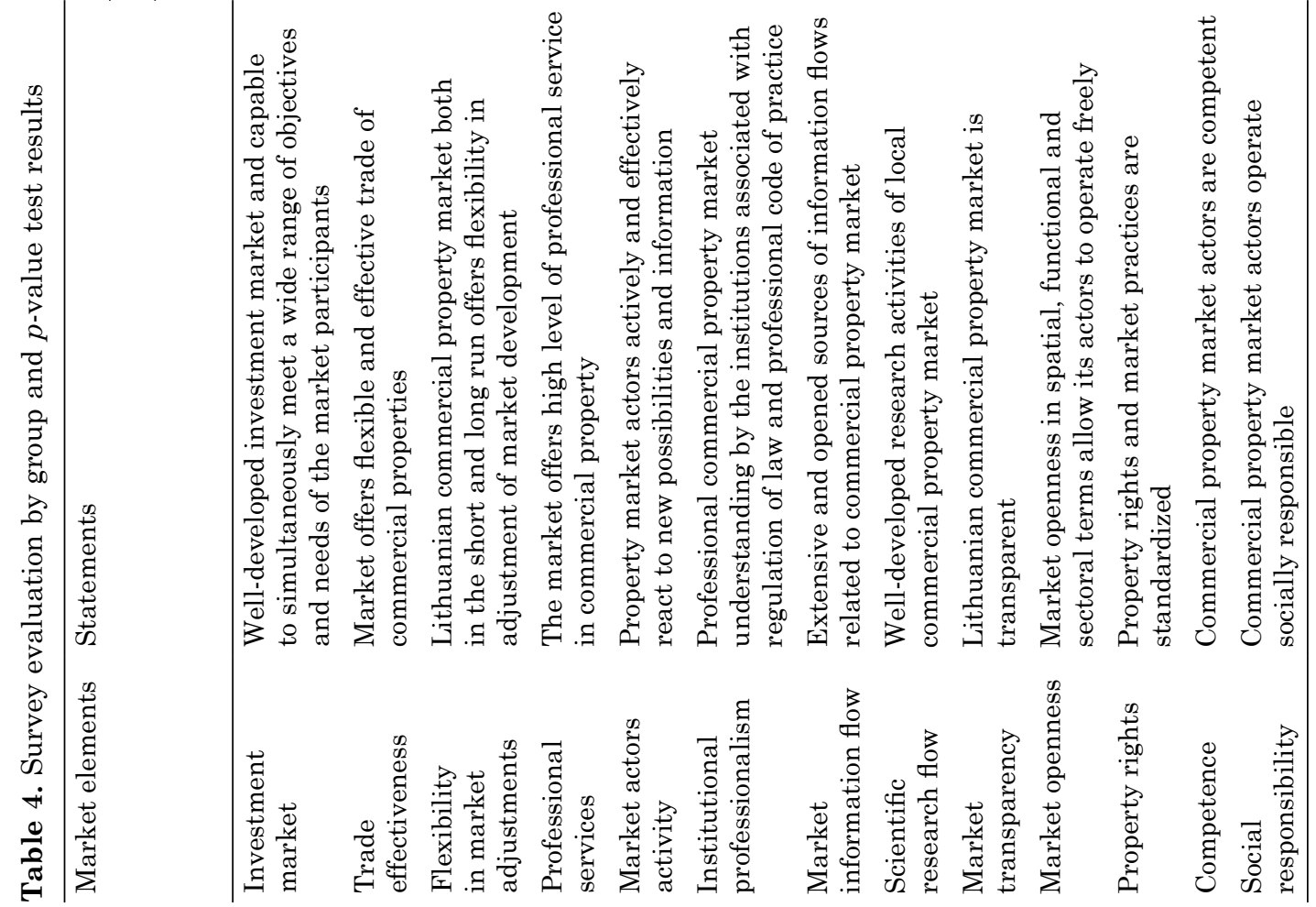


During the test, the hypothesis is defined as follows:

$\mathrm{H}_{0}$ : all three groups of participants evaluated the commercial property market maturity level as equally significant;

$\mathrm{H}_{\mathrm{A}}$ : all three groups of participants evaluated the commercial property market maturity level as not equally significant.

\section{THE ANALYSIS AND RESULTS OF THE RESEARCH}

An indicator of any theoretical concept needs to be both reliable and valid. In fact, reliability value represents the relationship between an indicator and the concept it is supposed to represent. In other words, it refers to the consistency of responses to a set of questions for measuring the concept (Shelby 2011). For computing reliability of the survey Cronbach's alpha coefficient was used; its result was reasonable enough -0.820 . It should be noted that Cronbach's alpha coefficient points out good internal consistency $(0.8 \leq \alpha<0.9)$ of the items in the scale and therefore demonstrates that the survey can be considered as acceptable and reliable.

The analysis of the survey transcripts showed that Lithuanian commercial property market maturity level is still in its maturing phase (or emergent as of Chin, Dent 2005), since mean ranged from 2.5 to 3.3 (Fig. 4). Despite the low overall evaluation of the market maturity level, respondents mostly agreed that:

- Commercial property market offers quite developed professional services in (3.3);

- The market's participants perform relatively effective response to new possibilities and information (3.2);

- The investment market is rather developed and simultaneously meets a wide range of objectives and needs of the market participants (3.0);

- Information flows on commercial property market are wide and opened (3.0);

- The market both in the short and long run offers flexibility in adjustment of market development (3.0);

- Qualified commercial property market understanding within institutions associated with regulations and law of practice (3.0).

The results also showed that the least respondents tend to agree with the facts that:

- Research activity on the local commercial property market is extensive (2.5);

- Commercial property market participants operate socially responsible (2.5);

- Lithuanian commercial property market is transparent (2.6);

- Trade within the local commercial property market is flexible and effective (2.7);

- Property rights and market practices are standardized (2.7).

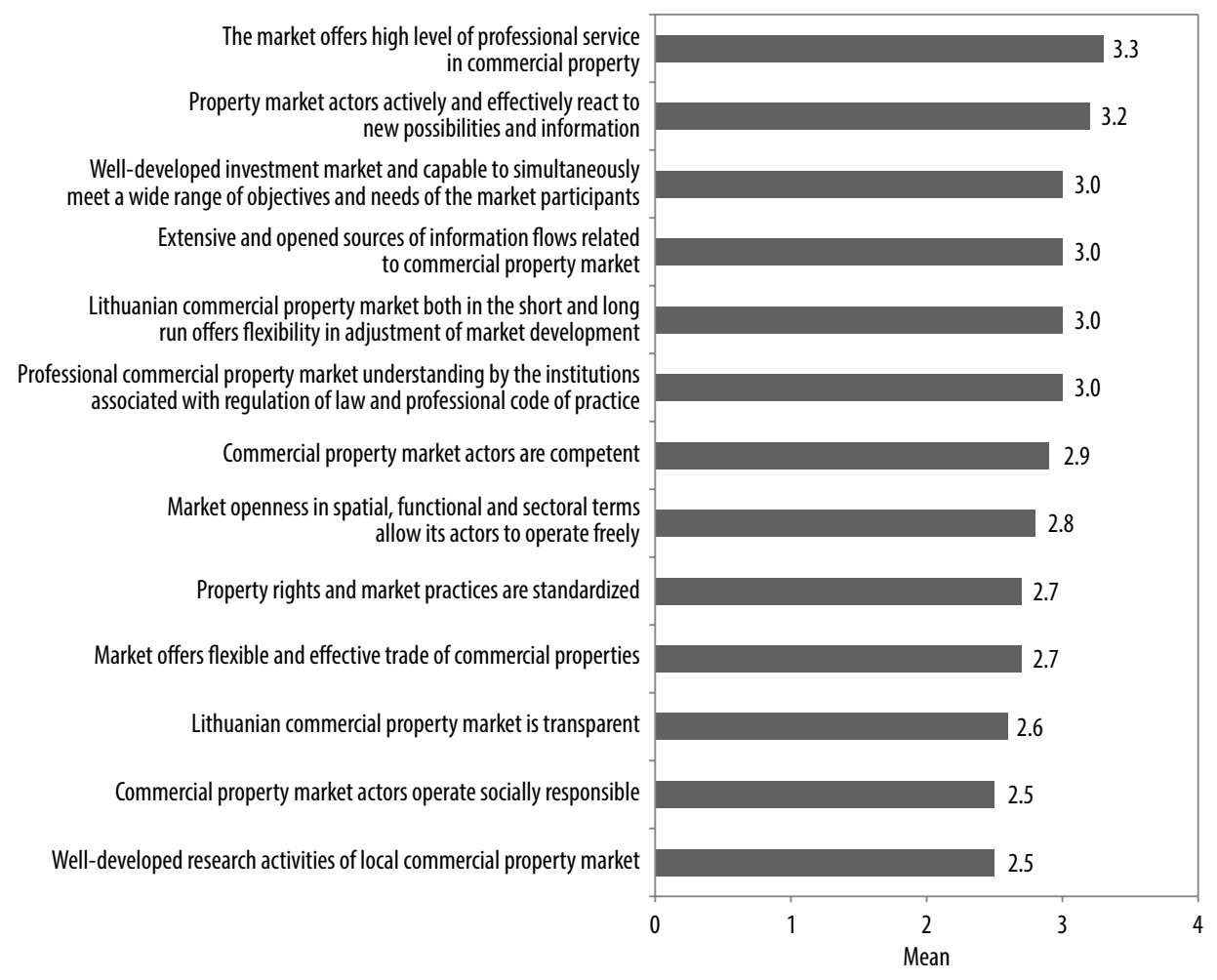

Fig. 4. Mean scores of commercial property market maturity elements 
In order to determine whether respondent groups rate the commercial property market maturity level significantly differently, a hypothesis defined in methodology was tested. Based on the test results, the $p$-value in most cases is smaller than $5 \%$. A bigger value of $p$ shows a better agreement between the marks. Since $p$-value $<0.05=$ $\alpha, \mathrm{H}_{0}$ hypothesis is rejected and $H_{A}$ fail to reject and therefore accepted. At the $\alpha<0.05$ level of significance, there exists sufficient evidence to conclude that there is a significant difference among market producers, institutions and, experts' opinions based on the majority of the statements of the survey (see Table 4). The values of the standard deviations given in Table 3 show that the marks of the different experts are scattered around the mean values similarly.

Notably, market producers ranked higher maturity level of Lithuanian commercial property market more frequently. Having evaluated statements individually, it became apparent that market producers were significantly more willing, comparing to other groups, to accept that the investment market in Lithuania is well-developed and simultaneously meets objectives and needs of the market participants; there is a high level of professional services in commercial property market, there is flexibility in adjustment of market development; the market is more transparent and opened in spatial, functional and sectoral terms, property rights and market practices are standardized, market participants actively and effectively react to new possibilities and information, operate socially responsible and are competent. As a result and directly influencing the performance of this group, the market producers overall provided a better assessment of the maturity level.

For institutions, on the other hand, property market maturity in Lithuania ranked in a more negative and weaker manner. Representatives of this group provided significantly low rates assigned to qualified commercial property market understanding within institutions associated with regulations and law of practice; it tended to agree less that information flows are wide and opened and that there is a broad selection of scientific researches in connection to the local commercial property market.

The overall results suggest that although market has travelled a long distance over the past decade and all the elements emerged greatly, yet there is a strong need for further improvements towards maturity. One of the major constrains to mature market is local culture of property market.
Countries where privatization has coincided with the collapse of the communist regime evidence embezzlement of state property (Brezis, Schunytzer 2003), corruption and bureaucracy (Cohen, Galinienè 2012) in one way or another influencing political and economic order, economic growth and overall investment climate in Lithuania. According to the Corruption Perceptions Index which measures level of public corruption in 176 countries, in 2012 Lithuania ranked 5.4 points out of a possible 10 and comparing to 2011 improved 0.6 points (Transparency International 2012).

Other major barriers to attractiveness and competitiveness of the Lithuanian property market can be characterized by low volume of transactions and small market size. Small countries have difficulties in attracting large-scale investment. According to Clark and Lund (2000) market size and volume of the transaction are the main barriers to attracting major international investors in the market. Bigger investors require attractive turnover volume for entering a country. Meanwhile, low-scale investment or lack of large deals in the market can be a significant barrier to enter the market and attracts less attention of international investors. This is a common problem of markets with small economies and therefore their goal is to offer competitive advantage and always work towards its improvement.

The creation of enriched investment environment and flexibility to adjust to the market driven forces, recognizing the need and adapting to the requirements of international companies are ultimate aims of small countries. In this respect Lithuania offers some advantages including well educated population, infrastructural development, strategic business location being the gateway to Russia and Belarus, aspiration to become Northern European IT innovation centre for the region by 2020 and attract investments to added-value sectors such as IT services. Property investors and developers see some opportunities that offers yield gap between current and historical rate; there is a scope to narrow and shrink. Yet, these competitive advantages only enhance general country's investment environment, whereas have little or no impact on other property market maturity elements. In this respect and in light of this research the strength should be made on the research and studies conducted in regards to the commercial property market, improve transparency by both market data availability and reliability, improve overall participants' social responsibility by minimizing bureaucracy and corruption, by implement- 
ing principals of sustainable development in property market and develop the market towards its efficiency - deliver the property products required by the economy at the prevailing price.

\section{CONCLUSIONS AND OUTLOOK}

The goal of this paper was to evaluate how maturity of Lithuanian commercial property market has improved to date. It can be concluded that the evolution of the Lithuanian market has undergone big transformation in all aspects of market development. The biggest influence to the market evolution was through institutional changes, privatization, and the impact of globalization. Significant improvement of the commercial property market took place over the course of the past 12 years, which can be characterized by development of qualitative and quantitative factors, affecting moods and behavior of the participants and improving competitiveness. Nevertheless, maturity of the property market is a constantly developing process with no absolute finished accomplishment. Current study proposes a model which suggests that level of maturity is strongly connected to competitiveness of the market. Employing broader number of elements in measuring Lithuanian property market maturity the results of the study clearly show that:

- commercial property market has gradually developed in terms of quality of professional services;

- participants of the market became more active and improved their awareness of the changes within the property market and its development;

- regulations and law of practice have advanced;

- the flow of the market information has become more extensive and opened;

- availability of reliable market data has improved;

- the transparency level is improved poorly;

- there is still a profound need for researches, institutional improvement, and social responsibility.

Property market development towards maturity in Lithuania is on its upward path. Although it is time-consuming process and tremendous changes have been already accomplished, the industry of the commercial property market in Lithuania is in its maturing phase and there is a great need for its improvement in every single element of the market to perform potential globally. The key to mature property market is constant improvement in market's competitiveness.

\section{REFERENCES}

Adair, A.; Berry, J.; McGreal, S.; Sýkora, L.; Parsa, A. G.; Redding, B. 1999. Globalization of real estate markets in Central Europe, European Planning Studies 7(3): 295-305. http://dx.doi.org/10.1080/09654319908720519

Adair, A.; Allen, S.; Berry, J.; McGreal S. 2006. Central and Eastern European property investment markets: issues of data and transparency, Journal of Property Investment \& Finance 24(3): 211-220. http://dx.doi.org/10.1108/14635780610659928

Barras, R. 1994. Property and the economic cycle: building cycles revisited, Journal of Property Research 11(3): 183-197. http://dx.doi.org/10.1080/09599919408724116

Brezis, E. S.; Schnytzer, A. 2003. Why are the transition paths in China and Eastern Europe different? A political economy perspective, Economics of Transition 11(1): 3-23.

Chin, H.; Dent, P. 2005. An analysis of the level of maturity in South-East Asian property markets, Pacific Rim Property Research Journal 11(4): 355-372.

Clark, E.; Lund, A. 2000. Globalization of a commercial property market: the case of Copenhagen, Geoforum 31(4): 467-475.

http://dx.doi.org/10.1016/S0016-7185(00)00015-4

Cohen, V. 2012. Komercinio nekilnojamojo turto rinkos modeliai ir veiksniai globalizacijos kontekste, Turto vertinimo teorijos ir praktikos apybraižos 2012 . Lietuvos turto vertintoju asociacija. Vilnius: Vilniaus universiteto leidykla, 18-29. (In Lithuanian)

Cohen, V.; Galinienè, B. 2012. Lietuvos nekilnojamojo turto rinka - brandumo link. Viešieji ir privatūs aktyvai: transformaciju, efektyvaus naudojimo ir vertinimo aspektai. Vilnius: Vilniaus universiteto leidykla, 14-20. (In Lithuanian)

Cronbach, L. J.; Shavelson, R. J. 2004. My current thoughts on coefficient alpha and successor procedures, Educational and Psychological Measurement 64(3): 391-418. http://dx.doi.org/10.1177/0013164404266386

D’Arcy, E.; Keogh, G. 1998. Territorial competition and property market process: an exploratory analysis, Urban Studies 35(8): 1215-1230. http://dx.doi.org/10.1080/0042098984330

D’Arcy, E.; Keogh, G. 1999. The property market and urban competitiveness: a review, Urban Studies 36(5-6): 917-928. http://dx.doi.org/10.1080/0042098993277

Dipo, D. R.; Soekarno, S. 2012. Business cycle and sectoral performance: a study on Indonesian capital market from period of 2002-2011, in Proceedings of the $2^{\text {nd }}$ international conference on business, economics, management and behavioral sciences, 13-14 October 2012, Bali, Indonesia, 105-108.

Egerová, D.; Jiřincová, M.; Lančarič, D.; Savov, R. 2013. Applying the concept of diversity management in organisations in the Czech Republic and the Slovak Republic - a research survey, Technological and Economic Development of Economy 19(2): 350-366. http://dx.doi.org/10.3846/20294913.2013.798598

George, D.; Mallery, P. 2003. SPSS for Windows step by step: a simple guide and reference. 11.0 update. $4^{\text {th }}$ ed. Boston: Allyn \& Bacon. 
Gliem, J. A.; Gliem, R. R. 2003. Calculating, interpreting and reporting Cronbach's alpha reliability coefficient for Likert-type scales, in Proceedings of the Midwest research to practice conference in adult, continuing and community education, 8-10 October 2003, The Ohio State University, Columbus, OH, 82-88.

Ivanauskas, F.; Eidukevičius, R.; Marčinskas, A.; Galinienè, B. 2008. Analysis of the housing market in Lithuania, International Journal of Strategic Property Management 12(4): 271-280. http://dx.doi.org/10.3846/1648-715X.2008.12.271-280

Jakeliūnas, S. 2010. Lietuvos krizès anatomija. Kaunas: Kitos knygos. (In Lithuanian)

Jones Lang Lasalle. 2007. European capital market bulletin 2007. Jones Lang Lasalle.

Kauko, T. 2012. End in sight? On the (un)sustainability of property development in the Budapest region, International Journal of Strategic Property Management 16(1): 37-55. http://dx.doi.org/10.3846/1648715X.2011.600781

Keogh, G.; D'Arcy, E. 1994. Market maturity and property market behaviour; a European comparison of mature and emergent markets, Journal of Property Research 11(3): 215-235. http://dx.doi.org/10.1080/09599919408724118

Keogh, G.; D’Arcy, E. 1999. Property market efficiency: an institutional economic perspective, Urban Studies 36(13): 2401-2414.

http://dx.doi.org/10.1080/0042098992485

Kolbre, E.; Kallakmaa-Kapsta, A. 2006. Housing market development in Estonia: is there a real estate boom?, Working Papers in Economics, School of Economics and Business Administration, Tallinn University of Technology (TUTWPE no. 146), 20: 27-46.

Lee, S. 1999. The European real estate market, in Proceedings from the Pacific Rim Real Estate Society conference, 26-30 January 1999, Kuala Lumpur, Malaysia.

Lee, S. 2001. The risks of investing in the real estate markets of the Asian region, Working Paper, Department of Land Management, The University of Reading Whiteknights, Reading, RG6 6AW, England.

Lim, C. L. 2000. Property investor behavior and perception of investment in Southeast Asia with particular reference to Singapore, $\mathrm{PhD}$ Thesis, University of Ulster, Ireland.

McGreal, S.; Parsa, A.; Keivani, R. 2002. The evolution of property investment markets in Central Europe: opportunities and constraints, Journal of Property Research 19(3): 213-230.

http://dx.doi.org/10.1080/09599910210151323
Ober Haus. 2012. Real estate market report Baltic State capitals: Vilnius, Riga, Tallinn. Available at: http:// www.ober-haus.lt

Ramanauskas, T. 2005. Banku kredito didejjimas makroekonominiu požiūriu, Pinigu studijos 3: 78-97. (In Lithuanian)

Raslanas, S.; Lukošienè, I. 2013. The determination of rents in shopping centers during recession period in Lithuania, International Journal of Strategic Property Management 17(3): 221-232. http://dx.doi.org/10.3846/1648715X.2013.819389

Ritzer, G. 2003. The globalization of nothing, SAIS review 23(2): 189-200.

Rykiel, Z. 1998. Globalization and transformation in Poland, GeoJournal 45(1-2): 141-144. http://dx.doi.org/10.1023/A:1006853613869

Seek, N. H. 1996. Institutional participation in the Asia Pacific real estate markets: are benefits worth the risks?, Real Estate Finance 12(4): 51-58.

Shelby, L. B. 2011. Beyond Cronbach's alpha: considering confirmatory factor analysis and segmentation, Human Dimensions of Wildlife 16(2): 142-148. http://dx.doi.org/10.1080/10871209.2011.537302

Tamošaitienè, J.; Gaudutis, E. 2013. Complex assessment of structural systems used for high-rise buildings, Journal of Civil Engineering and Management 19(2): 305-317.

http://dx.doi.org/10.3846/13923730.2013.772071

Tasan-Kok, T. 2007. Global urban forms and local strategies of property market actors, Journal of Housing and the Built Environment 22(1): 69-90.

http://dx.doi.org/10.1007/s10901-006-9067-0

Transparency International. 2012. Corruption Perceptions Index 2012. Available at: http://www.transparency.org/research/cpi/overview

Watkins, D.; Merrill, C. 2003. Central Europe: a brief introduction to participating in reemerging real estate markets, Heitman Real Estate Investment Management, Chicago, IL.

Wu, H.; Wong, S. K.; McKinnell, K.; Reed, R.; Robinson J. 2009. Commercial property markets and property cycles in Chinese cities, in the $15^{\text {th }}$ Pacific Rim real estate society conference, 18-23 January 2009, Sydney, Australia.

Zinbarg, R.; Revelle, W.; Yovel, I.; Li, W. 2005. Cronbach's $\alpha$, Revelle's $\beta$, and Mcdonald's $\omega_{H}$ : their relations with each other and two alternative conceptualizations of reliability, Psychometrika 70(1): 123-133. http://dx.doi.org/10.1007/s11336-003-0974-7 